\title{
Presidential Term Limits and the African Union
}

\section{Micha Wiebusch*}

SOAS University of London; University of Antwerp; UN University Institute on Comparative Regional Integration Studies

mwiebusch@cris.unu.edu

\author{
Christina Murray** \\ University of Cape Town \\ christina.murray@uct.ac.za
}

\begin{abstract}
A growing number of states have modified constitutionally determined presidential term limits or adopted a flexible interpretation of relevant constitutional provisions to allow incumbent leaders additional terms in the highest office. This article investigates African Union (AU) responses to attempts to overturn or weaken term limits on executive power, one of the most tenacious constitutional trends in Africa. Inspired by the AU's well-established discourse on "unconstitutional changes of government" under the African Charter on Democracy, Elections and Governance, the article frames the manipulation of presidential term limits as "undemocratic changes of the constitution". From this perspective it argues for a more active role for the $\mathrm{AU}$ in monitoring and enforcing constitutionalism and respect for democratic standards by member states when they amend their constitution. It concludes with a tentative set of principles to guide processes of constitutional change in Africa.
\end{abstract}

\section{Keywords}

African Union, presidential term limits, constitutionalism, rule of law, constitutional manipulation, African Charter on Democracy Elections and Governance

\section{INTRODUCTION}

Africa has become a key landscape for presidential tenure reform over the past 20 years, with more than 50 attempted or successful changes to presidential term limits (to introduce or tighten them, or to remove or relax them) in African Union (AU) member states. Until now much of the literature has

* Associate research fellow, UN University Institute on Comparative Regional Integration Studies; associate research fellow, University of Antwerp, Institute of Development Policy; research fellow $(\mathrm{PhD})$, School of Law, SOAS University of London.

* Senior adviser, Standby Team of Mediation Advisers, UN Department of Political Affairs; emeritus professor of human rights and constitutional law, Faculty of Law, University of Cape Town. 
concentrated on the virtues of presidential term limits and argued for their existence or even for an obligation to impose them. ${ }^{1}$ This position has been followed to a large extent by the AU, in particular the AU Commission, which has argued for a continent-wide adoption of limits on the number of terms a president may serve. ${ }^{2}$ Even more emphatically, in 2015, Economic Community of West African States (ECOWAS) heads of state formally debated (but did not reach agreement on) a proposal to adopt a regional obligation to adopt term limits. ${ }^{3}$

Nonetheless, there has been considerable resistance to attempts to impose or tighten term limits. Moreover, even when term limit changes pose threats to peace, there is an apparent institutional reluctance to interfere too vigorously. Like other international organizations, ${ }^{4}$ the $\mathrm{AU}$ is sensitive to the need for the broad support of its members and to arguments that it should not interfere in domestic matters. Against this background, this article suggests that the debate on term limits should be situated in the AU's approach to constitutionalism and the rule of law, including its agreed role in promoting and protecting these norms. Specifically, it argues that the AU already has a normative framework in place that commits its members to constitutionalism and the rule of law, and that this provides the basis for developing a more robust monitoring mechanism for scrutinizing and assessing the way in which presidential term limits are imposed, altered or removed. This argument is built on the 2000 Lomé Declaration on the Framework for an Organisation of African Unity Response to Unconstitutional Changes of Government (Lomé Declaration) and the 2007 African Charter on

1 See, for example, M Bratton "The 'alternation effect' in Africa" (2004) 15/4 Journal of Democracy 147; G Maltz "The case for presidential term limits" (2007) 18/1 Journal of Democracy 128; C Fombad and NA Inegbedion "Presidential term limits and their impact on constitutionalism in Africa" in C Fombad and C Murray (eds) Fostering Constitutionalism in Africa (2010, Pretoria University Law Press) 1; N Cheeseman "African elections as vehicles for change" (2010) 21/4 Journal of Democracy 139.

2 According to the AU Commission, which is the AU's executive arm and secretariat, "[c]onstitutional and legal frameworks should determine the tenure and number of terms that a head of state and government can stand for elections". See Report of the Interim Chairperson on the Proceedings of the African Conference on Democracy, Elections and Governance (communiqué of the Pretoria Conference on Elections, Democracy and Governance, organized by the AU Commission in collaboration with the Electoral Commission of South Africa, EX/CL/35 (III)) (copy on file with the authors).

3 "Regionwide presidential term limit proposal dropped" (5 August 2015) Economist Intelligence Unit, available at: <http://country.eiu.com/article.aspx?articleid=1163405 $300 \&$ Country=Togo\&topic $=$ Politics\&subtopic=Forecast\&subsubtopic=Political + stability $\&$ $\mathrm{u}=1$ \&pid=297227613\&oid=297227613\&uid=1 > (last accessed 14 January 2019).

4 See C Murray, E Alston and M Wiebusch "Presidential term limits and the international community" in A Baturo and R Elgie (eds) The Politics of Presidential Term Limits (forthcoming, Oxford University Press). 
Democracy, Elections and Governance (ACDEG), among other instruments, as well as a variety of policy frameworks and decisions from AU institutions. ${ }^{5}$

For the purposes of this article (which only considers presidents who are directly elected and have executive powers), presidential term limits are defined as explicit temporal restrictions on the ability of a president to hold the top executive office. This has two consequences. First, we are not concerned with non-temporal limitations (eligibility criteria) that restrict a person from holding presidential office (including, for example, age limits). ${ }^{6}$ Secondly, restricting the analysis to situations in which a directly elected president has executive authority excludes the three monarchies in Africa (Morocco, Lesotho and Swaziland) and parliamentary systems like those in Ethiopia, Somalia and Mauritius where the president is head of state but does not exercise executive functions. The Sahrawi Arab Democratic Republic is excluded as its president is indirectly elected by delegates of the sole political party, the Polisario Front. In addition, South Africa and Botswana are excluded because both have parliamentary systems, in neither of which is the president directly elected. Proposals for term limits for the head of the executive in parliamentary systems are becoming more common and in both South Africa and Botswana the indirectly elected head of the executive is subject to term limits. These countries are nonetheless excluded because indirect election is accompanied by a different range of accountably mechanisms and thus raises somewhat different questions in relation to term limits from those in countries with direct election to the highest executive office. Most notably, the heads of the executive in a parliamentary system do not have fixed terms and Parliament can relieve them of their position at any time. ${ }^{7}$

The plethora of recent term limit changes in Africa provides the empirical material to trace the AU's record in dealing with term limits and evaluate its action. This article argues that, while an increasingly robust approach to

5 These institutions include the Peace and Security Council, the African Commission on Human and Peoples' Rights, the African Court on Human and Peoples' Rights and the African Peer Review Mechanism.

6 The authors' survey of the 55 constitutions of AU member states found at least 19 different categories of eligibility criteria for assuming the presidency, including nationality, religion, age, possession of political and civil rights, criminal record, physical and mental capacities, moral capacities, residency, property, professional incommensurability, professional qualifications, educational qualifications, national liberation credentials, public declaration of assets, financial requirements, popular support, political party membership, no secret society membership and parliamentary eligibility. Some countries, such as Cameroon, Comoros and Tunisia, refer to law or organic law to develop presidential eligibility criteria further.

7 In parliamentary systems, governments, including the head of the executive, can usually be removed by a vote by members of the legislature (called a vote of no confidence). In contrast, presidents with fixed terms can usually only be removed by special (and onerous) procedures, which set more or less objective requirements. Importantly, unlike the situation in a parliamentary system, a directly elected president cannot be removed because of a political difference between him or her and the legislature. 
undemocratic practices can be observed over the past 20 years, the AU's response to the democratic backsliding that characterizes many term changes remains highly uneven and ineffective. If the AU is to embrace its agenda on conflict prevention and democratic consolidation seriously, among other things, an earlier and more robust engagement with proposed changes to presidential term limits is called for, as they often trigger violence and other constitutional crises. To contribute to this agenda, this article offers several suggestions on how the AU can adopt a more effective role in evaluating and responding to often intricate and complex constitutional manipulation, including in the case of changes to term limits.

The next section of this article provides a brief historical overview of presidential term limits, mapping out how and why they came about on the continent and describing the different forms they take. The following section starts by setting out how term limits have been changed between 2000 and 2018 and the different processes for changing them in African constitutions. It concludes by arguing that three sets of factors (instability, illegality and illegitimacy) often signal constitutional manipulation. The article then considers the role of the AU in relation to term limits, particularly when constitutional manipulation may be present. Here it sets out the elements of the AU's normative and institutional framework that provide the basis for its involvement in domestic constitutional processes, and sketches the key legal and institutional challenges that inhibit its ability to implement its goal of democratic constitutionalism. The article concludes by proposing a set of four principles to guide the $\mathrm{AU}$ in implementing its concurrent agendas of conflict prevention, democratic governance monitoring and human rights enforcement in the context of constitutional amendment. The principles elaborate on the AU's existing normative framework and draw on the factors identified in the article as signalling possible constitutional manipulation, to tailor the framework to the specific context of constitutional change.

\section{AFRICA AND PRESIDENTIAL TERM LIMITS}

The traditional view is that term limits originated in the political arrangements of the Ancient Greeks and Romans. ${ }^{8}$ Centuries later this idea persists and term limits have become an increasingly familiar institution in modern constitutions, particularly as a restriction on executive power. With the advent of major waves of decolonization on the African continent in the 1960s and the adoption of new constitutions to shape the exercise of power in the new states, term limits entered the African constitutional landscape (such as in Togo in 1963) although, at this point, few African states adopted them. However, over time, the necessity of dealing with an overly strong executive

8 T Ginsburg, J Melton and Z Elkins "On the evasion of executive term limits" (2011) 52 William and Mary Law Review 1806 at 1818; BM Dulani Personal Rule and Presidential Term Limits in Africa (PhD thesis, 2011, Michigan State University) at 63. 
wielding power in ways that harmed the socio-economic and political development of a country became undeniable. ${ }^{9}$ Patronage systems (usually based on family or identity politics), serious violations of rights, abuse of security forces (often to hold onto power) and almost routine electoral corruption when elections were actually held, had become commonplace ${ }^{10}$ and increasingly unsustainable. After the Cold War, a broad consensus emerged in favour of democratization and consolidation of democratic institutions ${ }^{11}$ and, gradually, constitutional mechanisms that seek to tackle the problems of excessive executive power were adopted. These mechanisms included strengthened legislatures, ${ }^{12}$ decentralization ${ }^{13}$ and protection of judicial independence. ${ }^{14}$ Limits on the duration and number of terms a president may hold office is one of these mechanisms. They are now frequently seen as part of the toolbox to protect democracy, together with regular free and fair elections, and the protection of fundamental rights embedded in African constitutional fabrics. ${ }^{15}$ By 2000, the idea of term limits was widespread in Africa and widely supported by civil society organizations in particular. However, on a continent with 55 states, divergences are likely and consensus on presidential term limits has not yet been achieved.

In Africa, as elsewhere, term limits vary along two dimensions: the length of a term and the number of terms a president can serve. All democracies set the length of the term a president may serve. ${ }^{16}$ In Africa it ranges between four and seven years. While 37 states set terms of five years, a small number permit

9 See, for example, HK Prempeh "Progress and retreat in Africa: Presidents untamed" (2008) 19/2 Journal of Democracy 109; HK Prempeh "Presidential power in comparative perspective: The puzzling persistence of imperial presidency in post-authoritarian Africa" (2008) 35/4 Hastings Constitutional Law Quarterly 761.

10 See, for example, N Cheeseman and B Klaas How to Rig an Election (2018, Yale University Press).

11 See, for example, NJ Udombana "Articulating the right to democratic governance in Africa” (2004) 24 Michigan Journal of International Law 1209 and HK Prempeh "Africa's 'constitutionalism revival': False start or new dawn?" (2007) 5/3 International Journal of Constitutional Law 469.

12 JD Barkan “Legislatures on the rise?" (2008) 19/2 Journal of Democracy 124; R Mattes and S Mozaffar "Legislatures and democratic development in Africa" (2016) 59/3 African Studies Review 201.

13 N Steytler "Domesticating the leviathan: Constitutionalism and federalism in Africa" (2016) 24/2 African Journal of International and Comparative Law 272; A Dyzenhaus "Decentralisation: Accountability in local government" in N Cheeseman (ed) Institutions and Democracy in Africa: How the Rules of the Game Shape Political Developments (2018, Cambridge University Press) 327.

14 W Egbewole (ed) Judicial Independence in Africa (2017, Wildy, Simmonds and Hill).

15 HK Prempeh “Africa's 'constitutionalism revival', above at note 11.

16 Historical examples of states without limits on the duration of the presidential mandate are the "presidents for life" introduced in Malawi (Hastings Banda 1971-93), Equatorial Guinea (Francisco Macías Nguema 1972-79), Central Africa Republic (Jean-Bédel Bokassa 1972-76), Tunisia (Habib Bourguiba 1975-87) and Uganda (Idi Amin 1976-79). 
four, six or seven years. ${ }^{17}$ However, term limit debates usually centre around re-election. In states with limits on re-election, the norm is to allow re-election only once. The Republic of Congo is currently the only outlier, permitting a third term. ${ }^{18}$ Limits on mandate renewal may be strengthened or relaxed by complementary provisions. The constitutions of Benin, Burkina Faso and Niger are among those that underline the term limit by expressly stipulating an absolute maximum of two terms. Other countries weaken the limit on re-election by specifying a limit on the number of consecutive terms rather than a total, lifetime limit. Mozambique, Equatorial Guinea and GuineaBissau are among those that limit mandates to two consecutive terms but allow re-election after sitting out one term. For an overview of the variety of presidential term limits in African states, see Table 1.

\section{CHANGING PRESIDENTIAL TERM LIMITS IN AFRICA}

\section{Trends and reverse trends: African term limits over the past two decades}

When assessing democratization in Africa from the early 1990s, academic commentators have suggested that there is a trend towards presidential term limits. ${ }^{19}$ However, from April 2000 to July 2018, limits were changed 47 times in 28 countries $^{20}$ and at least six further attempted changes failed. ${ }^{21}$ In 23 cases, spread over 19 countries, the changes strengthened term limits by introducing or imposing stricter temporal boundaries on presidential mandates, but in 24 instances in 18 countries the temporal restrictions on holding presidential office were removed or loosened.

17 Three states permit four years (Egypt, Ghana and Nigeria), two states permit six years (Chad and Liberia) and four states permit seven years (Burundi, Cameroon, Equatorial Guinea and Gabon).

18 Other constitutions that provided for a maximum of three terms in the past include those of Seychelles (1993), Madagascar (1998) and Tunisia (1959).

19 HK Prempeh "Africa's 'constitutionalism revival', above at note 11.

20 As of November 2018, term limit changes in Gambia and Sudan were pending but not finalized, so these changes are excluded from the analysis.

21 These include Zambia (2001), Malawi (2002), Nigeria (2006), Burkina Faso (2014) and Benin (2005 and 2017). Changing term limits has been discussed on many more occasions, but this study is limited to cases in which proposed change had a fair chance of success and does not consider cases in which proposals to change term limits are, among other things, part of opposition activism without a realistic chance of success or at the level of undisclosed cabinet meetings. 
Table 1 Presidential term limits in Africa (2018)

\begin{tabular}{|c|c|c|c|c|c|c|c|c|c|}
\hline COUNTRIES & Renewable & $\begin{array}{c}\text { Renewable } \\
\text { once }\end{array}$ & $\begin{array}{c}\text { Renewable } \\
\text { twice }\end{array}$ & $\begin{array}{l}\text { Max two } \\
\text { consecutive } \\
\text { terms }\end{array}$ & $\begin{array}{l}\text { Max two } \\
\text { terms } \\
\text { altogether }\end{array}$ & $\begin{array}{c}4 \\
\text { years }\end{array}$ & $\begin{array}{c}5 \\
\text { years }\end{array}$ & $\begin{array}{c}6 \\
\text { years }\end{array}$ & $\begin{array}{c}7 \\
\text { years }\end{array}$ \\
\hline Algeria & & $\mathrm{x}$ & & & & & $x$ & & \\
\hline Angola & & & & & $x$ & & $x$ & & \\
\hline Benin & & $x$ & & & $x$ & & $x$ & & \\
\hline Burkina Faso & & $x$ & & & $x$ & & $x$ & & \\
\hline Burundi & $\mathrm{x}$ & & & $\mathrm{x}$ & & & & & $x$ \\
\hline Cameroon & $x$ & & & & & & & & $x$ \\
\hline $\begin{array}{l}\text { Central African } \\
\text { Republic }\end{array}$ & & $x$ & & $x$ & & & $x$ & & \\
\hline Cape Verde & $\mathrm{x}$ & & & $x$ & & & $x$ & & \\
\hline Chad & & $x$ & & & & & & $x$ & \\
\hline Côte d'Ivoire & & $x$ & & & & & $x$ & & \\
\hline Comoros* $^{*}$ & & $\mathrm{x}$ & & & & & $\mathrm{x}$ & & \\
\hline Congo & & & $\mathrm{x}$ & & & & $\mathrm{x}$ & & \\
\hline Djibouti & $x$ & & & & & & $\mathrm{x}$ & & \\
\hline $\begin{array}{l}\text { Democratic Republic of } \\
\text { Congo (DRC) }\end{array}$ & & $x$ & & & & & $x$ & & \\
\hline Egypt & & $x$ & & & & $\mathrm{x}$ & & & \\
\hline Equatorial Guinea & $x$ & & & $x$ & & & & & $\mathrm{x}$ \\
\hline Eritrea & & & & & $x$ & & $x$ & & \\
\hline Gabon & $x$ & & & & & & & & $\mathrm{x}$ \\
\hline The Gambia** & $x$ & & & & & & $x$ & & \\
\hline Ghana & & & & & $x$ & $x$ & & & \\
\hline Guinea-Bissau & $x$ & & & $x$ & & & $x$ & & \\
\hline
\end{tabular}


Table 1 Continued

\begin{tabular}{|c|c|c|c|c|c|c|c|c|c|}
\hline COUNTRIES & Renewable & $\begin{array}{c}\text { Renewable } \\
\text { once }\end{array}$ & $\begin{array}{c}\text { Renewable } \\
\text { twice }\end{array}$ & $\begin{array}{l}\text { Max two } \\
\text { consecutive } \\
\text { terms }\end{array}$ & $\begin{array}{l}\text { Max two } \\
\text { terms } \\
\text { altogether }\end{array}$ & $\begin{array}{c}4 \\
\text { years }\end{array}$ & $\begin{array}{c}5 \\
\text { years }\end{array}$ & $\begin{array}{c}6 \\
\text { years }\end{array}$ & $\begin{array}{c}7 \\
\text { years }\end{array}$ \\
\hline Guinea & & $\mathrm{x}$ & & & $\mathrm{X}$ & & $\mathrm{x}$ & & \\
\hline Kenya & & & & & $\mathrm{x}$ & & $\mathrm{x}$ & & \\
\hline Liberia & & & & & $x$ & & & $\mathrm{X}$ & \\
\hline Libya ${ }^{\star \star \star}$ & & $x$ & & & & & $\mathrm{x}$ & & \\
\hline Madagascar & & $x$ & & & & & $x$ & & \\
\hline Malawi & & & & $\mathrm{x}$ & & & $x$ & & \\
\hline Mali & & $\mathrm{X}$ & & & & & $\mathrm{X}$ & & \\
\hline Mauritania & & $\mathrm{x}$ & & & & & $\mathrm{x}$ & & \\
\hline Mozambique & $x$ & $x$ & & $x$ & & & $x$ & & \\
\hline Namibia & & & & & $\mathrm{X}$ & & $\mathrm{X}$ & & \\
\hline Nigeria & & & & & $x$ & $x$ & & & \\
\hline Niger & & $x$ & & & $\mathrm{x}$ & & $\mathrm{x}$ & & \\
\hline Rwanda & & $\mathrm{x}$ & & & & & $\mathrm{x}$ & & \\
\hline Senegal & & & & $x$ & & & $\mathrm{x}$ & & \\
\hline Seychelles & & & & & $\mathrm{x}$ & & $\mathrm{x}$ & & \\
\hline Sierra Leone & & & & & $\mathrm{X}$ & & $\mathrm{x}$ & & \\
\hline South Sudan** & $x$ & & & & & & $\mathrm{x}$ & & \\
\hline São Tomé and Príncipe & $x$ & & & $x$ & & & $x$ & & \\
\hline Sudan & & $x$ & & & & & $x$ & & \\
\hline Tanzania & & & & & $x$ & & $\mathrm{X}$ & & \\
\hline Togo & $x$ & & & & & & $x$ & & \\
\hline Tunisia & & & & & $\mathrm{x}$ & & $x$ & & \\
\hline
\end{tabular}




\section{Table 1 Continued}

\begin{tabular}{|c|c|c|c|c|c|c|c|c|c|}
\hline COUNTRIES & Renewable & $\begin{array}{c}\text { Renewable } \\
\text { once }\end{array}$ & $\begin{array}{c}\text { Renewable } \\
\text { twice }\end{array}$ & $\begin{array}{c}\text { Max two } \\
\text { consecutive } \\
\text { terms }\end{array}$ & $\begin{array}{l}\text { Max two } \\
\text { terms } \\
\text { altogether }\end{array}$ & $\begin{array}{c}4 \\
\text { years }\end{array}$ & $\begin{array}{c}5 \\
\text { years }\end{array}$ & $\begin{array}{c}6 \\
\text { years }\end{array}$ & $\begin{array}{c}7 \\
\text { years }\end{array}$ \\
\hline Uganda & & & & & $\mathrm{X}$ & & $\mathrm{x}$ & & \\
\hline Zambia & & & & & $x$ & & $\mathrm{x}$ & & \\
\hline Zimbabwe & & & & & $x$ & & $x$ & & \\
\hline $\begin{array}{l}\text { Total Countries } \\
\text { (out of } 46 \text { ) }\end{array}$ & 12 & 18 & 1 & 9 & 18 & 3 & 37 & 2 & 4 \\
\hline
\end{tabular}

${ }^{*}$ Re-election is possible once. In addition, the presidency rotates among islands with a maximum of two consecutive terms for each Island (Comoros Constitution 2001 , revised in 2018, art 52)

**No mention of term limits

*** Draft constitution

Source: Authors' own compilation, based primarily on the Comparative Constitutions Project dataset, available at: <http://www.comparativeconstitutionsproject.org> (last accessed

14 January 2019). 
The lack of consensus on term limits is also evident in the diversity of the changes. On some occasions term limits were introduced or removed; other changes were incremental, chipping away at existing term limits or strengthening them. Successful resistance to term limits led to four distinct types of constitutional amendments. The first set of amendments extended the length of presidential terms of office: from five to seven years in Guinea (2001), Republic of Congo (2002), Rwanda (2003) and Burundi (2018); and from five to six years in Chad (2018). Presidential terms were also extended de facto in an ad hoc manner due to intra-state conflict and capacity problems when elections were postponed in South Sudan (2015 and 2018) and DRC (2016). ${ }^{22}$ Secondly, changes increased the number of terms a person may hold presidential office, from one to two in Comoros (2018) and from two to three in the Republic of Congo (2015). Thirdly, changes were made to reset the clock for the incumbent president in Zimbabwe (2013), Republic of Congo (2015) and Rwanda (2015), where the incumbents had reached their absolute term limits but could argue that a new or revised constitution enabled them to start with fresh mandates unrestricted by previous constitutional limits. Fourthly, term limits were removed altogether in Guinea (2001), Togo (2002), Tunisia (2002), Gabon (2003), Chad (2005), Uganda (2005), Algeria (2008), Cameroon (2008), Niger (2009) and Djibouti (2010).

This record of successfully weakening term limits is roughly matched by instances in which term limits have been introduced or strengthened by one of five distinct types of constitutional amendments. The first set of constitutional changes introduced term limits in Côte d'Ivoire (2000), Senegal (2001), DRC (2006), Equatorial Guinea (2011) and Egypt (2014) and re-introduced term limits in Burkina Faso (2000), Niger (2010), Algeria (2016), Uganda (2017) and Chad (2018). Secondly, changes shortened the presidential term: from seven to five years in Burkina Faso (2000), Côte d'Ivoire (2000), Senegal (2001 and 2016), DRC (2006) and Rwanda (2015); from six to five years in Central African Republic (2004), Mauritania (2006) and Zimbabwe (2013); and from six to four years in Comoros (2001) and Egypt (2014). Thirdly, changes were also introduced to reduce the number of terms a person may serve, from three to two in Madagascar (2010) and the Seychelles (2016). Fourthly, term limits were clarified and tightened, by stating expressly that the limit is absolute and does not merely restrict the number of consecutive terms a person may serve. In Burkina Faso (2015) the constitution was amended to provide that no-one may serve more than two terms in office whether consecutive or not. ${ }^{23}$ Similarly, when Niger re-introduced term limits in 2010 , an absolute limit was imposed. Finally, some constitutions introduced more onerous

22 Elections in South Sudan were postponed and the incumbent's presidential mandate extended twice by constitutional amendments adopted by Parliament. In DRC, the Constitutional Court decided that the president may stay in power until a newly elected president is installed.

23 Constitution of Burkina Faso (2015), art 37. 
amendment procedures for term limits or made them entirely unamendable. In Rwanda and Sierra Leone a referendum is now required to approve changes to presidential tenure, a requirement that was met in Rwanda in 2015. In other countries, presidential term limits were permanently fixed by being declared unamendable; in 2016 Algeria made the number of term renewals unamendable and several other countries have made both the number and duration of terms unamendable. ${ }^{24}$

Contests over term limits have also taken place in courts, with mixed outcomes. For example, in Burkina Faso (2005) and Senegal (2012) the Constitutional Courts decided that the constitutional amendment stipulating a change to the term limit was not applicable to the incumbent Presidents Blaise Compaoré and Abdoulaye Wade, respectively. Both were permitted to run again, but only Compaoré was victorious. In Burundi (2015), the Constitutional Court decided that, although the constitution limits presidents to two terms, President Pierre Nkurunziza's first term did not count because on that occasion he was not elected by the people of Burundi but by Parliament. ${ }^{25}$ This argument, which permitted him to be elected for a third term, was particularly controversial because, under the 2000 Arusha Accords, on which the constitution is based, Nkurunziza's first term would have counted as one of his two permitted terms. ${ }^{26}$ Nonetheless, he won the elections to serve a third term. In contrast, in Benin, the Constitutional Court protected presidential term limits in various decisions, including by declaring them unamendable in 2011. ${ }^{27}$ Yet more boldly, in Malawi, judicial interpretation strengthened limits on presidential terms by interpreting the constitution to set an absolute limit on the number of terms a president may serve although it provides for a "maximum of two consecutive terms". ${ }^{28}$ In 2009, Bakili Muluzi was declared ineligible to stand for election by the Malawian Electoral Commission because he had already served for two terms (1994-2004). He appealed against the decision, as he interpreted the limit on "consecutive" terms to allow him to run again after sitting out at least one term. However, the High Court sided with the Electoral Commission, reading the limitation on "consecutive terms" to mean absolute terms. ${ }^{29}$

24 See note 34 below.

25 The justification of the Burundian Constitutional Court is similar to that of the Namibian Parliament when it permitted Sam Nujoma to run for a third term in 1999.

26 See $S$ Vandeginste "Legal loopholes and the politics of executive term limits: Insights from Burundi” (2016) 16/2 Africa Spectrum 39.

27 See SH Adjolohoun "Made in courts' democracies? Constitutional adjudication and politics in African constitutionalism" in CM Fombad (ed) Constitutional Adjudication in Africa (2017, Oxford University Press) 247 at 273.

28 Constitution of Malawi (1994), art 83(3).

29 State $v$ Ex Parte Muluzi and Another (2 of 2009) [2009] MWHC 13 (16 May 2009). Incidentally, when in office, Muluzi launched an unsuccessful campaign to remove term limits. 


\section{Changing presidential term limits: Procedures and practices}

Presidential term limits are typically set out in a country's constitution. Procedures for introducing, amending and removing them are usually those for constitutional amendment, which tend to include: special procedural rules making amendment more difficult than passing an ordinary law; a search for broad national consensus; and a multitude of actors. Together these aspects of constitutional change reflect an understanding that constitutions should be more stable than ordinary laws and broadly agreed upon as setting the basic rules for the exercise of political power (including respect for rights) and the resolution of disputes.

First, special procedures that make constitutional amendment particularly onerous may include higher majority thresholds, requirements of multiple readings in Parliament, special timeframes to ensure full discussion of proposed amendments and special requirements for the publication of amendment proposals. ${ }^{30}$ Now, increasingly, even more rigid constraints are imposed on particular (or even all) constitutional amendments. Most obviously, requiring a referendum for an amendment to be adopted makes the process more onerous (although in some cases it may be used to bypass the need to secure cross-party support in a legislature). Indeed, Abebe describes Africa as a "proreferendum" continent on the basis of the number of countries that require referenda for some or all constitutional amendments. ${ }^{31}$ Table 2 reflects the number of cases in which term limits were changed by referendum since 2000 . In addition, so-called "unamendable" or "eternity" clauses, providing that certain provisions may never be changed, are becoming more common. ${ }^{32}$ Several African constitutions include such clauses, ${ }^{33}$ and occasionally presidential term limits are declared to be unamendable. ${ }^{34}$

30 See CM Fombad "Some perspectives on durability and change under modern African constitutions" (2018) 11/2 International Journal of Constitutional Law 382; T Ginsburg and J Melton "Does the constitutional amendment rule matter at all? Amendment cultures and the challenges of measuring amendment difficulty" (2015) 13/3 International Journal of Constitutional Law 686; R Dixon "Constitutional amendment rules: A comparative perspective” in R Dixon and T Ginsburg (eds) Comparative Constitutional Law (2011, Edward Elgar) 96.

31 A Abebe "Taming regressive constitutional amendments: The African Court as a continental (super) constitutional court" International Journal of Constitutional Law (forthcoming).

32 Y Roznai "Unconstitutional constitutional amendments: The migration and success of a constitutional idea" (2013) 61/3 American Journal of Comparative Law 657.

33 The authors' survey of 55 AU constitutions revealed at least 15 categories of unamendable clauses: republican character of the state and / or government; monarchical character of the state; democratic credentials; human rights credentials; linguistic credentials; (territorial) integrity or unity of the state or cohesion among people; symbolic credentials; term limits; independence; reconciliation; decentralization; state of war, siege, emergency or exceptional powers; presidential vacancy; eligibility criteria; and amnesties.

34 States that currently have unamendable clauses on presidential term limits include Burkina Faso, Central African Republic, Niger, DRC, Madagascar, Guinea, Mauritania, Senegal, Tunisia, Algeria and Egypt. 


\section{Table 2: Changing term limits in Africa in practice (2000-18): Main decision-makers}

\begin{tabular}{lll}
\hline \multicolumn{1}{c}{ Parliament } & \multicolumn{1}{c}{ Referendum } & \multicolumn{1}{c}{ Judiciary } \\
\hline $\begin{array}{l}\text { Burkina Faso (2000, } \\
\text { 2015) }\end{array}$ & Côte d'Ivoire (2000) & Burkina Faso \\
Togo (2002) & Guinea $(2001,2010)$ & Malawi (2009) \\
Gabon (2003) & Senegal $(2001,2016)$ & Benin (2011) \\
Algeria (2008, 2016) & Republic of Congo (2002, 2015) & Senegal (2012) \\
Cameroon (2008) & Tunisia (2002) & Burundi (2015) \\
Senegal (2008) & Rwanda (2003, 2015) & DRC (2016) \\
Djibouti (2010) & Central African Republic (2004, & (Total 6) \\
Tunisia (2014) & 2016) & \\
South Sudan (2015, & Chad (2005) & \\
2018) & Uganda (2005) & \\
Seychelles (2016) & DRC (2006) & \\
Uganda (2017) & Mauritania (2006) & \\
Chad (2018) & Niger (2009, 2010) & \\
(Total 15) & Madagascar (2010) & \\
& Equatorial Guinea (2011) & \\
& Egypt (2012) & \\
& Zimbabwe (2013) & \\
Overall total: 47 & Burundi (2018) & \\
\hline
\end{tabular}

Source: Authors' own compilation.

Secondly, as many constitutional amendments change the social contract by changing how power is exercised and by whom, it is now widely accepted that change should be built on a broad social consensus. What consensus means in this context is often disputed. It seldom if ever means full agreement of all social groups. Instead, it seems to be shorthand for a requirement that, in addition to the transparency expected of all government action, significant constitutional amendments should be accompanied by public information, education programmes and special processes that allow the views of citizens to be considered and deliberated upon. ${ }^{35}$

Thirdly, processes to change constitutions tend to depend on a more diverse set of actors than ordinary law-making processes: the formal rules for constitutional change may involve more institutions and the political stakes often generate engagement from many sectors. For example, amendment processes may include special commissions that report on the need for or advisability of

35 The ACDEG confirms this interpretation in art 10(2): "State Parties shall ensure that the process of amendment or revision of their constitution reposes on national consensus, obtained if need be, through referendum." Accepting that a referendum may reflect national consensus suggests that consensus does not mean unanimity. 
amendment, legislative bodies or committees, executive institutions, the judiciary, ${ }^{36}$ political parties, civil society, media, sometimes the military or other representatives of the state security apparatus and, if a referendum is required for the amendment to be adopted, electoral management bodies.

\section{Constitutional manipulation of term limits}

All these presidential term limit changes have followed the procedure set out in the relevant constitution, as measured purely formally: required majorities were achieved and required referenda held. ${ }^{37}$ However, superficial compliance with constitutional requirements may mask constitutional manipulation, when powerful groups engineer constitutional change to serve their interests and often simply to remain in power. ${ }^{38}$ Apparent formal compliance with requirements poses the challenge of assessing whether or not they have been followed in the manner that the constitution intended and that respects the normative understanding of constitutionalism embraced by the AU (set out below). In that regard, consensus is growing on several contextual factors that might signal problems with constitutional change and that the AU could use to inform its responses.

There are three clusters of factors that may signal constitutional manipulation: instability, illegality and illegitimacy (see Table 3). First, serious violence, including police crackdowns (for example Cameroon 2008 and Congo 2015), political assassinations and political party-affiliated militia attacks (for example Burundi in 2015), street protests and damage to property (for example Zimbabwe in 2013 and Burkina Faso in 2014), during a process of constitutional change, indicate that deeper problems may exist. Such conditions cannot constitute conclusive evidence that a process of constitutional change has been manipulated; they do not, on their own, justify a refusal to recognize the changes as compliant with continental norms concerning democracy and the rule of law. If they were, among other things, those resisting change would be encouraged to engage in violence to delegitimize changes and secure their positions. Nonetheless, such conditions always raise serious questions about the process, and often, particularly, about the role of security forces.

36 As discussed below, courts may be involved when processes are challenged or when it is argued that amendments conflict with fundamental constitutional principles. See, for instance, Ex Parte Chairperson of the Constitutional Assembly: In Re Certification of the Constitution of the Republic of South Africa 1996 (4) SA 744 (CC); L Juma and C Okpaluba "Judicial intervention in Kenya's constitutional review process" (2012) 11 Washington University Global Studies Law Review 287; J Colon-Rios "Beyond parliamentary sovereignty and judicial supremacy: The doctrine of implicit limits to constitutional reform in Latin America” (2013) 44 Victoria University of Wellington Law Review 521.

37 This confirms the "formal institutionalization" thesis of Posner and Young in D Posner and D Young "The institutionalization of political power in Africa" (2007) 18/3 Journal of Democracy 126.

38 See similarly D Tull and C Simmons "The institutionalisation of power revisited: Presidential term limits in Africa" (2017) 52/2 Africa Spectrum 79. 


\section{Table 3: Examples of indicators of constitutional manipulation}

\begin{tabular}{|c|c|c|}
\hline Instability & Illegality & Illegitimacy \\
\hline $\begin{array}{l}\text { Political assassinations } \\
\text { Detention of politicians }\end{array}$ & $\begin{array}{l}\text { Restrictions on political } \\
\text { participation rights }\end{array}$ & $\begin{array}{l}\text { Low turnout during a } \\
\text { referendum }\end{array}$ \\
\hline Suppression of protests & Restrictions on political & Opposition boycott \\
\hline Police violence & communication rights & Personalization of politics \\
\hline Militia violence & Suppression of opposition & Questionable judicial \\
\hline Property damage & parties & independence \\
\hline $\begin{array}{l}\text { Use of emergency } \\
\text { measures }\end{array}$ & $\begin{array}{l}\text { Electoral fraud during a } \\
\text { referendum }\end{array}$ & $\begin{array}{l}\text { Questionable parliamentary } \\
\text { independence }\end{array}$ \\
\hline \multirow[t]{3}{*}{$\begin{array}{l}\text { Domestic deployment of } \\
\text { the military }\end{array}$} & Political corruption & $\begin{array}{l}\text { Questionable civil-military } \\
\text { relations }\end{array}$ \\
\hline & & $\begin{array}{l}\text { Non-inclusive and } \\
\text { non-participatory } \\
\text { constitutional dialogue }\end{array}$ \\
\hline & & $\begin{array}{l}\text { Lack of transparency in } \\
\text { constitutional reform process }\end{array}$ \\
\hline
\end{tabular}

Source: Authors' own compilation.

Secondly, if constitutional change is accompanied by violations of laws protecting fundamental rights, the process is undermined. Illegality may be signalled by violations of freedom of expression, association and assembly that restrict political debate. For example, protests may be banned (Congo 2015), opposition members may be locked up (Rwanda 2015), electronic communication channels may be suspended (Congo 2015) or journalists may be harassed (Gabon 2003). Bribery or intimidation of relevant decision makers, including referendum voters (Equatorial Guinea 2011), parliamentarians (Nigeria 2005) or judges (Burundi 2015), also signal a flawed process.

Instability and illegality will usually also lead to the third set of factors: those indicating illegitimacy. Violence, especially abuse of security forces, and disregard for the law undermine the legitimacy of a process. A lack of legitimacy may also be a result of exclusionary practices, the lack of credibility of proposed changes or an absence of transparency, among other things. Opposition boycotts (as in Congo 2002, Djibouti 2010 and Congo 2015) may signal illegitimacy, as may low turnouts in referenda on constitutional change, such as those in Egypt (2014) and Senegal (2016), which were under 40 per cent. Similarly, the credibility of constitutional change may be thrown into doubt when it is marked by a personalization of power. If a constitution is changed to benefit only one individual (for example Rwanda 2015 and South Sudan 2018), it is reasonable to ask whether the change respects the constitutional arrangements (in the case of Rwanda, term limits; in the case of South Sudan, the length of a particular term). Illegitimacy may also be inferred from manipulative practices involving key democratic institutions. For instance, in Niger (2009), preceding an attempt to remove presidential term limits through 
a constitutional referendum, the president dissolved Parliament and the Constitutional Court, which had contested the legality of this initiative. In the Republic of Congo (2015), the Constitutional Court allowed a referendum relaxing presidential term limits, despite a clear and explicit ban on the constitutional reform of presidential term limits.

Of course, instability, illegality and illegitimacy are interrelated. For example, violence causing instability may violate human rights and result in the overall illegitimacy of the process. But regardless of how they may interconnect, what is important is that they are considered in assessing the validity of a constitutional amendment. This is increasingly recognized by external actors. As the next section shows, to some extent the relevance of these factors is articulated in continental law and in the mandates of continental institutions. However, this article argues that the current AU legal framework and monitoring arrangements are inadequate for the complicated task of assessing the constitutionality of processes of constitutional amendment.

\section{AFRICAN UNION AND PRESIDENTIAL TERM LIMITS}

\section{Normative and institutional framework}

The AU's engagement with constitutional change in its member states, particularly presidential term limit changes, is linked to its ambitions to secure stability and peace on the continent, to promote and protect human rights, and to foster a culture of democratic governance. ${ }^{39}$ As noted in the Introduction above, the consensus in favour of democratization and consolidation of democratic institutions that emerged in the $1990 \mathrm{~s}^{40}$ led the Organisation of African Unity (OAU), later the AU, to adopt a number of initiatives intended to improve the quality of democratic governance in its member states. These initiatives included setting standards and formalizing common principles and values related to constitutional democracy, ${ }^{41}$ as well as monitoring and evaluating member states' human rights, and electoral and governance systems through, respectively, the African Charter on Human and

39 See, generally, the operationalization of the African Peace and Security Architecture, the African human rights system and the African Governance Architecture.

40 See Declaration of the OAU Assembly of Heads of State and Government on the Political and Socio-Economic Situation in Africa and the Fundamental Changes Taking Place in the World, AHG/Decl.1 (XXVI) (1990). See also M Wiebusch, CC Aniekwe, L Oette and S Vandeginste "The African Charter on Democracy, Elections and Governance: Past, present and future" in this issue.

41 The AU's normative framework on democratic governance is built around various treaties, protocols, resolutions, declarations and decisions; for an overview, see African Governance Architecture "Shared values" instruments, available at: <http://agaplatform.org/index.php/about> (last accessed 14 January 2019). For an overview of the AU's normative and enforcement framework on protecting constitutionalism, see M Wiebusch The Role of Regional Organizations in the Protection of Constitutionalism (2016, International Institute for Democracy and Electoral Assistance). 
Peoples' Rights' (African Charter) state reporting mechanism ${ }^{42}$ and AU Election Observation Missions (AUEOMs), ${ }^{43}$ as well as the reporting systems under the African Peer Review Mechanism (APRM) ${ }^{44}$ and the ACDEG. ${ }^{45}$ The AU also developed an increasingly robust security architecture, coordinated mainly by the Peace and Security Council (PSC), its principal decision-making body for the prevention, management and resolution of conflicts. ${ }^{46}$ To this enforcement regime has been added the African Court on Human and Peoples' Rights (ACtHPR), ${ }^{47}$ which complements the African Commission on Human and Peoples' Rights (ACHPR) ${ }^{48}$ to protect human rights and which has a broad mandate extending to all human rights instruments ratified by a state party to a case. ${ }^{49}$

Within this emerging normative and institutional context, the (O)AU started paying closer attention to constitutions and the processes related to their change. The main instruments that establish constitutionalism as a basic principle of the AU are the AU Constitutive Act, the Lomé Declaration and the ACDEG. Generally, the commitment to constitutionalism can be read at two levels: in a formal sense (adoption and implementation of constitutions) and in a substantive sense (normative standards and principles). In stating that all AU member states should adopt, respect and adhere to constitutions, the Lomé Declaration imposes formal requirements. Later, in the legally binding ACDEG, 50 this formal understanding was supplemented by a commitment

42 See, for example M Evans and R Murray "The state reporting mechanism of the African Charter" in M Evans and R Murray (eds) The African Charter on Human and Peoples' Rights: The System in Practice 1986-2006 (2008, Cambridge University Press) 49.

43 See for example CC Aniekwe and SM Atuobi "Two decades of election observation by the African Union: A review" (2016) 15/1 Journal of African Elections 25.

44 Although the APRM was created outside the (O)AU system, the AU Assembly of Heads of State and Government decided to incorporate it into the structures of the AU. See 23rd ordinary session of the AU Assembly of Heads of State and Government in Malabo, Equatorial Guinea, June 2014 (Assembly/AU/Dec.527(XXIII)).

45 ACDEG, art 49. See also "Guidelines for state parties' reports under the ACDEG" (2016), annex, available at: <http://aga-platform.org/sites/default/files/2018-10/Rules\%20Of\% 20Procedure\%20FINAL.pdf $>$ (last accessed 13 February 2019). At the time of writing only one state (Togo) had submitted a report.

46 See Protocol Relating to the Establishment of the Peace and Security Council of the African Union (2002).

47 For an overview of the ACtHPR's recent practice, see L Burgorgue-Larsen and GF Ntwari "Chronique de jurisprudence de la Cour Africaine des Droits de l'Homme et des Peuples (2015-2016)" [Chronicle of jurisprudence of the African Court of Human and Peoples' Rights] (2018) 113 Revue Trimestrielle des Droits de l'Homme 127.

48 For an overview of ACHPR practice in protecting human rights, see Evans and Murray (eds) The African Charter, above at note 42.

49 Protocol to the African Charter on Human and Peoples' Rights on the Establishment of the African Court (1998), art 3(1).

50 Formally, the ACDEG is only binding on those states that have ratified it. As of January 2019, the ACDEG had been signed by 46 member states and ratified by 32 . However, this has not prevented the AU from invoking it in the political crises in states that have not ratified it, such as Egypt (2013-14), DRC (2016-18) or Gambia (2016-17). 
to the supremacy of the constitution in the political organization of the state, ${ }^{51}$ and the requirements that access to (and the exercise of) power must be in accordance with the constitution ${ }^{52}$ and that member states must take all appropriate measures to ensure constitutional rule. ${ }^{53}$ However, the AU is clearly committed to a more substantive understanding of constitutionalism. This "thick" 54 understanding of constitutionalism is reflected in the AU Constitutive Act, ${ }^{55}$ the Lomé Declaration ${ }^{56}$ and the ACDEG, ${ }^{57}$ as well as more recent $\mathrm{AU}$ reports. For example, for the AU Commission:

\begin{abstract}
"[C]onstitutionalism denotes limited government. It also entails protection of citizens against arbitrary rule. It is about the existence of clearly defined mechanisms for ensuring that the limitations on state power are legally enforceable. The core elements of constitutionalism include: (a) the recognition and protection of fundamental rights and freedoms; (b) the separation of powers; (c) an independent judiciary; (d) the review of the constitutionality of laws; (e) the control of the amendment of the constitution; and (f) institutions supporting constitutional democracy and accountability." 58
\end{abstract}

In the context of the more substantive understanding, the AU also provides normative guidance for the adoption and change of constitutions. For example, the Lomé Declaration stipulates that the "preparation, content and method of revision" of constitutions "should be in conformity with generally acceptable principles of democracy". The ACDEG expands on this by providing the safeguard that the process of constitutional amendment or revision requires national consensus, "obtained if need be, through referendum". ${ }^{59}$ In 2009, the PSC adopted the principle that "constitutions shall not be manipulated in order to hold on to power against the will of the people" and that "constitution-making or constitutional review processes shall not be driven by personal interests and efforts aimed at undermining popular aspirations" 60 while, in 2010, the AU Assembly of Heads of State and

51 ACDEG, art 10(1).

52 Id, art 3.

53 Id, art 5.

54 See D Feldman "'Which in your case you have not got': Constitutionalism at home and abroad” (2011) 64 Current Legal Problems 117; and, for the relationship between democracy and constitutions, K Scheppele "Autocratic legalism" (2018) 85 University of Chicago Law Review 545.

55 See AU Constitutive Act (2000), preamble and arts 4(m), 4(p) and 30.

56 See the set of common values and principles for democratic governance in the Lomé Declaration.

57 See ACDEG, preamble and particularly arts 2, 3, 4, 5, 10, 14, 15 and 32.

58 Report of the Commission on Governance, Constitutionalism and Elections in Africa (Assembly/AU/9(XXVI)) (2016), para 27 (copy on file with the authors).

59 ACDEG, art 10(2).

60 Ezulwini Framework for the Enhancement of the Implementation of Measures of the African Union in Situations of Unconstitutional Changes of Government in Africa (2009). 
Government reminded member states of the need to "uphold the rule of law and abide by their own Constitutions, especially with regard to constitutional reforms, bearing in mind that failure to respect these provisions could lead to situations of tension which, in turn, could trigger political crisis". ${ }^{61}$ These decisions also reflect the AU's recognition of the nexus between constitutional amendments and instability.

Beyond setting norms on constitutionalism, the AU has also developed an increasingly robust enforcement regime (coordinated mainly by the PSC, the AU Chairperson and the AU Commission Chairperson) to respond to military coups, rebel or mercenary overthrows of government or refusals to respect electoral outcomes. ${ }^{62}$ To these four scenarios the ACDEG adds that "any amendment or revision of the constitution or legal instruments, which is an infringement on the principles of democratic change of government ... [shall be considered] ... an illegal means of accessing or maintaining power ... [and] ... draw appropriate sanctions by the Union". 63 This last situation is of particular interest in the context of presidential term limits because the ACDEG's travaux préparatoires show that the drafters initially considered referring to the "[a]mendment or revision of constitutions and legal instruments, contrary to the provisions of the constitution of the State Party concerned, to prolong the tenure of office for the incumbent government". ${ }^{64}$ A consensus was clearly growing within the AU that term limit change needed to be addressed and possibly sanctioned. However, during the preparation of the ACDEG, Uganda (which had removed term limits in 2005) entered a reservation to this wording and, during the final meetings of the AU policy organs, other member states raised further objections. ${ }^{65}$ The rejection of the earlier proposal reflects the different positions among AU member states. Some see removing or weakening term limits as a direct challenge to the continental agenda of consolidating democratic institutions; others are wary of continental interference in what they see as internal affairs and, sometimes, more specifically, their agenda for prolonging the power of an incumbent president. Nonetheless, although the principles of democratic change of government remain poorly articulated, the ACDEG now formally confirms that, for the AU, certain constitutional provisions or certain processes of constitutional amendment will not comply with these principles. This means that changes

61 Decision on the Prevention of Unconstitutional Changes of Government and Strengthening the Capacity of the African Union (Assembly/AHG/Dec.269 (XIV)) (2010), para 6(ii)(a).

62 Lomé Declaration; ACDEG, art 23(1)-(4). The anti-coup norm has also been codified in other AU instruments including the AU Constitutive Act. See Wiebusch The Role of Regional Organizations, above at note 41.

63 ACDEG, art 23(5).

64 Report of the Ministerial Meeting on the Draft African Charter on Democracy, Elections and Governance (2006) (copy on file with the authors).

65 Ibid. Decision on the African Charter on Democracy, Elections and Governance (EX. CL/Dec.320 (X)) (2007). 
of government may infringe AU norms, even in the absence of the violence of a coup or disregard for the outcome of elections, for instance if they are based on manipulated constitutional change.

\section{Challenges}

The legal framework outlined above and the AU's "zero tolerance" of coups ${ }^{66}$ show the willingness within the AU system to uphold the principle that formal constitutional procedures must be adhered to, including when constitutions themselves are amended. This commitment of AU member states is reflected in the many processes to alter presidential term limits that adhered to the formal rules of constitutional change, as noted in this article. However, the AU's track record is much poorer when it comes to dealing with the problem envisaged in article 23(5) of the ACDEG, which may be termed "constitutional coups". ${ }^{67}$ Article 23(5) refers to situations where constitutions are amended to alter the rules concerning change in government by processes that do not meet AU standards of constitutionalism and the rule of law (and usually also fail to meet domestic standards underpinning the constitution itself).

The contrast between the AU's response to military coups and "constitutional coups" is most visible in political crises that involved both. For example, in Niger in 2009, although the PSC had endorsed the ECOWAS decisions to impose sanctions including suspension, because it considered that the constitutional referendum to remove presidential term limits violated the ECOWAS Supplementary Protocol on Democracy and Good Governance, the PSC did not actually impose sanctions. ${ }^{68}$ It was only when a military coup took place in 2010 that the PSC suspended Niger from all AU activities. ${ }^{69}$ The reason for this delayed response may be in part because Niger had signed but not yet ratified the ACDEG, leaving the AU without the legal basis to impose sanctions under article 23(5). However, in the case of Burkina Faso, a country that had ratified the ACDEG, the 2014 attempt by President Blaise Compaoré to remove presidential term limits did not lead the AU to consider action under article 23. Instead, it was only when the introduction of a bill in Parliament to change the constitution was followed, initially by a popular uprising that led to Compaoré's resignation, and then by a military coup triggered by leadership

66 See, for example, the AU response to sanction the military coups in Central African Republic (2003 and 2013), Mauritania (2008), Guinea (2008), Madagascar (2009), Niger (2010), Mali (2012), Guinea Bissau (2012), Egypt (2013) and Burkina Faso (2015).

67 See similarly P Manirakiza "Insecurity implications of unconstitutional changes of government in Africa: From military to constitutional coups" (2016) 17/2 Journal of Military and Strategic Studies 86.

68 PSC Communiqué of the 207th Meeting (29 October 2009), AU doc PSC/AHG/Comm3 (CCVII).

69 PSC Communiqué of the 216th Meeting (19 February 2010), AU doc PSC/PR/Comm 1 (CCXVI). 
disputes within the transitional government, that the PSC responded, threatening suspension and targeted sanctions. ${ }^{70}$

As the AU has recognized in a number of contexts, including its emerging policy on responding to popular uprisings, delaying a response to moments of crisis and focusing on adherence to formal constitutional amendment rules means both that opportunities to prevent conflict are missed and that disregard for broader constitutional norms agreed to at the continental level is not addressed. ${ }^{71}$ of course, early intervention is much more difficult from a political perspective than when constitutional rules are directly flouted. The European Union's experience in agreeing to an appropriate response to the disregard for the rule of law in Hungary and Poland provides a salutary example. ${ }^{72}$ However, we argue here that, without a firmer basis in its legal, policy and institutional arrangements, the AU will struggle to deal with the political challenges. To rectify this, two significant preliminary matters need to be addressed: legal uncertainty about "undemocratic changes of the constitution"; and the inadequacy of the AU's monitoring mechanisms.

As noted above, the Lomé Declaration, the ACDEG and other AU instruments commit AU member states to uphold the "principles of democracy", including during constitutional revisions. However, thus far, little has been done to give legal content to this and related principles. Certainly, article 23 (5) of the ACDEG recognizes the problem of constitutional manipulation when it states that constitutional change itself could be the basis of an unconstitutional change (or, clearly, retention) of power. However the provision leaves at least two questions open. What are the principles of democratic change of government in Africa? And when, if ever, is the process by which a constitution is amended relevant to determining that those principles have been "infringed"? Wrapped up in these questions are both the substantive issue of whether term limits are an element of democracy in Africa and a more procedural issue of what the process of constitutional change should comprise, when a constitutional amendment changes the processes for electing governments. To implement article 23(5) and other related AU principles, more clarity is needed on these issues.

The lack of clarity on article 23(5) may help explain the AU's poor response rate when constitutional amendment processes are marred by irregularities, such as those outlined above. In fact, the AU has not yet invoked article 23 (5) in any situation. Only in a 2016 AUEOM report on presidential elections

70 PSC Communiqué of the 465th Meeting (3 November 2014), AU doc PSC/PR/COMM. (CDLXV).

71 See PSC Communiqué of the 432nd Meeting (29 April 2014), AU doc PSC/PR/BR. (CDXXXII). On the AU's position vis-à-vis popular uprisings, see SA Dersso "The status and legitimacy of popular uprisings in the AU norms on democracy and constitutional governance" and P Manirakiza "Towards a right to resist gross undemocratic practices in Africa", both in this issue.

72 See C Closa and D Kochenov (eds) Reinforcing Rule of Law Oversight in the European Union (2016, Cambridge University Press). 
in Djibouti was a country reminded of the provision, in this case in light of the removal of term limits six years earlier. More agreement on the kind of situations to which article 23(5) and related AU principles apply would provide a more secure formal basis for AU responses to constitutional manipulation.

The mandates of monitoring mechanisms also require development. The AU has already taken great strides in establishing monitoring regimes. The growing AU practice of observing and critically evaluating elections in member states through AUEOMs has generally led to a better informed assessment of the quality of the electoral landscape and the level of democratic legitimacy of newly elected governments. The AU has expanded its understanding of election monitoring, covering a longer period, ${ }^{73}$ and produces more qualitative assessments of electoral campaigning, the adequacy of legal frameworks, participation and respect for fundamental democratic rights. However, these assessments generally take place after the alteration of a constitution. This has not prevented missions from occasionally raising concerns about an earlier constitutional amendment process. For example, reporting on the elections in the Republic of Congo in 2016, the AUEOM highlighted the opposition boycott of the constitutional referendum to approve a change to term limits the previous year. However, generally, and perhaps because of their narrow election observation mandate, AUEOMs avoid broader issues. Moreover, the scope of AUEOMs has generally been limited to observing presidential and parliamentary elections; ${ }^{74}$ they do not usually observe referenda. On a few occasions, the AU has sent a small, short-term observer team to monitor constitutional referenda (for example, Djibouti 1992, Togo 1999, Côte d'Ivoire 2000 and Mauritania 2006). Without consistent monitoring of constitutional referenda, the AU will not be able to respond to constitutional manipulation through dishonest referenda practices.

The most emphatic AU engagement with term limits is through the APRM. In assessing the state of the rule of law and supremacy of the constitution in countries under review, APRM country review teams are required to report on "whether the constitution clearly provides a fixed term or terms of office for the executive" and to describe "attempts (if any) to extend executive tenure by constitutional amendment". ${ }^{75}$ These APRM indicators clearly do not set a requirement of term limits, but they do reflect an awareness that, in Africa at least, term limits are considered to be connected to constitutionalism. ${ }^{76}$ Concern by the APRM about the process by which term limits are changed

73 Aniekwe and Atuobi "Two decades of election observation", above at note 43 at 33-35.

74 Decision on the Meeting of Experts on Elections, Democracy and Governance in Africa, EX.CL/Dec. 124(V) (2004).

75 Revised country self-assessment questionnaire for the APRM (2012).

76 For a similar view, see European Commission for Democracy Through Law (Venice Commission) Report on Term-Limits: Part I: Presidents (study no 908/2017, CDL-AD(2010) 015), adopted at 114th plenary session, Venice, 16-17 March 2018, available at: <http:// www.venice.coe.int/webforms/documents/default.aspx?pdffile=CDL-AD(2018)010-e> (last accessed 14 January 2019). 
is reflected, for example, in its report on Uganda. Here, the APRM linked its observation of "the increasing evidence of mounting authoritarianism and rapidly escalating corruption in the country" with the controversial constitutional amendment in 2005 to remove presidential term limits "despite strong opposition". ${ }^{77}$ It offered the cautious recommendation that the constitutional amendment that removed the two term limit should be reviewed with "the view of re-instating it (or not)" and to generate a "national consensus on term limits ... to deepen democracy". ${ }^{78}$ Similarly, in its 2016 report on Chad, the APRM noted the removal of presidential term limits in 2005 and recommended their re-establishment in order to harmonize its constitutional provisions with those generally in force in Francophone countries and to promote democratic change as a best practice. ${ }^{79}$ In 2018 , Chad complied with this APRM recommendation and re-instated the presidential term limit. In reporting on Benin, where term limits are in place, the APRM highlighted "democratic changeover at the helm of affairs: expressing a shared culture of democracy, tolerance and fair play" as a good practice to be emulated by others. $^{80}$

While the APRM seems to be overtly in favour of presidential term limits, it is generally silent on the formal process by which term limits are changed or challenged, with the exception of its report on Uganda. This is a lost opportunity, because the APRM's mandate is broad and recognizes that constitutionalism and good governance are not a matter of rules alone. This is evident in the APRM's critical reporting on Rwanda, where it observed that "[p]olitical parties may be de jure authorized but de facto impossible to realise and operate freely" 81 and that "political pluralism has been made subject to strict guidelines for political competition and the spreading of ideas", 82 and commented that "[t]he Constitution tends to treat inclusion and competition as antagonistic rather than as complementary". ${ }^{3}$ In addition, in relation to the separation of powers in Rwanda, the APRM reports that the principle is observed "in the Constitution but, in practice, the powers of the executive override the judiciary". ${ }^{84}$ Similarly, in its report on Uganda, the APRM notes that "[a]lthough the Constitution prescribes the separation of powers among the key organs of the state, in actual practice the dominance of the executive over the judiciary and the legislature is the norm and hampers the equilibrium between power and checks and balances". ${ }^{85}$ Although APRM reviews are not directly concerned with constitutional change and APRM country review teams cannot

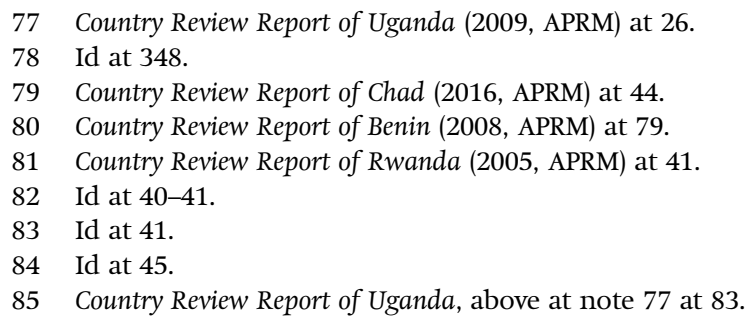


usually monitor the conditions under which a constitution is changed, they do seek to report on the broader climate of democracy and governance in the countries under review. ${ }^{86}$ In other words, through the APRM, the principle that the general state of democracy and governance can be monitored is established and has been implemented. The next step of applying this approach consistently to the political context in which constitutional change occurs is not a large one. Moreover, the APRM does provide for a special review mechanism that can be launched when early warning signs suggest an impending political, social or economic crisis in a member country. ${ }^{87}$ This mechanism could provide the mandate for a monitoring mission in the context of constitutional changes. However, it has never been used.

Thus, the APRM's mandate and practice provide a good basis for monitoring constitutional amendment processes. However, only 20 country assessments have been completed over the past 15 years, although 37 states signed up. Moreover, the actual implementation of recommendations has remained limited. ${ }^{88}$ In addition, like the AUEOM, if APRM reviews do consider a process of constitutional amendment, they will usually do so retrospectively.

Continental human rights institutions are also increasingly engaging with constitutional amendments and the conditions relevant to democratic constitutional changes, again setting standards for the AU system. The ACHPR and the ACtHPR have built on the African Charter and other human rights instruments to develop guidance to promote and protect key democratic rights, including the right to participate in government and the rights to freedom of association, assembly ${ }^{89}$ and expression..$^{90}$ On at least one occasion, the ACHPR's work was directly linked to controversies related to presidential term limits: the ACHPR's protective mandate led to a fact-finding mission, requested by the PSC, to "investigate all forms of human rights violations and other abuses committed in Burundi since the beginning of the crisis

86 An exception is the APRM review of Zambia (2013), which provides a thoughtful analysis of the country's constitutional review process. In that case, the 2011 country review overlapped with (rather than being triggered by) a process of constitutional change. Eventually, Parliament rejected the proposed constitutional amendments, but that did not prevent the APRM from critically reviewing the proposals. See Country Review Report of Zambia (2013, APRM) at 274-79.

87 Revised country self-assessment questionnaire for the APRM (2012).

88 S Gruzd and Y Turianskyi "The African Peer Review Mechanism at 15: Achievements and aspirations" (2018) 170 SAIIA Policy Briefing 1 at 2.

89 See, for example, the ACHPR "Guidelines on freedom of association and assembly in Africa" (2017) and the ACHPR "Guidelines for the policing of assemblies by law enforcement officials in Africa" (2017). See also the various ACHPR resolutions on the right to freedom of association, expression and participation in government.

90 For examples of the ACtHPR's freedom of expression jurisprudence, see: Abdoulaye Nikiema, Ernest Zongo, Blaise Ilboudo and Burkinabe Human and Peoples' Rights Movement v Burkina Faso ACtHPR 013/2011; Lohe Issa Konaté $v$ Burkina Faso (Konaté) ACtHPR 004/2013; and Ingabire Victoire Umuhoza v Republic of Rwanda (Ingabire) ACtHPR 003/2014. 
[related to the third term of the president] in April 2015". ${ }^{91}$ Other cases have involved constitutional changes more generally. For example, the ACHPR found substantive violations of the African Charter in the context of constitutional amendments relating to presidential eligibility criteria, ${ }^{92}$ banning of political parties ${ }^{93}$ and the independence of the judiciary. ${ }^{94}$ The ACtHPR found the constitutional change in Tanzania that banned independent electoral candidates to be in violation of the African Charter and ordered the state to remedy the violations. ${ }^{95}$ The court also found that Côte d'Ivoire's electoral law violated the African Charter, the ACDEG and the ECOWAS Protocol on Democracy and Good Governance, because the imbalanced composition of its election management body in favour of the ruling regime failed to provide an adequate guarantee of the institution's independence and impartiality. ${ }^{96}$ Remarkably, in reaching this conclusion, the court also relied on a similar critique formulated in the AUEOM report on the presidential election of 25 October 2015. ${ }^{97}$ This is an excellent illustration of how AUEOM's monitoring role can be complemented by the court's binding enforcement mechanism to protect key democratic rights. However, a further opportunity for the ACtHPR to develop principles related to constitution change was lost when Rwanda held its 2015 referendum to approve a term limit extension before the case challenging its legality had been heard. The applicants had alleged the violation of various rights, including the "freedom to participate in government" and a violation of the ACDEG, which, they argued, prohibited "amendments of constitutions to extend term limits for the presidency". ${ }^{98}$

91 Report of the Delegation of the African Commission on Human and Peoples' Rights on its Fact-Finding Mission to Burundi (7-13 December 2015), available at: <https://www. uantwerpen.be/images/uantwerpen/container2673/files/Burundi\%20DPP/conflit/oig/ CADHP0516E.pdf> (last accessed 31 January 2019). In its final report, the ACHPR eventually found a series of violations of the human rights set out in the African Charter, arts 2 (freedom from discrimination), 3 (equality before the law and equal protection of the law), 4 (life), 5 (prohibition of torture and inhumane treatment), 6 (personal liberty and protection from arbitrary arrest), 7 (fair trial), 9 (information), 10 (freedom of association), 11 (freedom of assembly), 13 (participation in government), 14 (property), 16 (health), 17 (education) and 23 (national and international peace and security).

92 Legal Resources Foundation v Zambia ACHPR 211/98; Mouvement Ivorien des Droits Humains (MIDH) v Côte d'Ivoire Commission 246/02.

93 Lawyers for Human Rights $v$ Swaziland ACHPR 251/02.

94 Ibid.

95 Tanganyika Law Society and Legal and Human Rights Centre and Reverend Christopher R Mtikila $v$ United Republic of Tanzania ACtHPR 009 and 011/2011.

96 Actions Pour la Protection des Droits de l'Homme $v$ Republic of Côte d'Ivoire (APDH $v$ Côte d'Ivoire) ACtHPR 001/2014. For analysis of this case, see B Kioko "The African Charter on Democracy, Elections and Governance as a justiciable instrument" and G Niyungeko "The African Charter on Democracy, Elections and Governance as a human rights instrument", both in this issue.

97 APDH $v$ Côte d'Ivoire, id, para 132.

98 Order on the request for interim measures Kayumba Nyamwasa and Others $v$ Republic of Rwanda ACtHPR 016/2015, para 8. 
They also alleged that the campaign to amend the constitution "has been conducted in a climate of fear" and that the question of the constitutionality of any amendments could not be dealt with by the Rwandan judicial system as the courts are not independent. ${ }^{99}$ They requested interim measures, including an order that President Kagame should respect term limits and cancel the planned referendum. The very fact that African citizens could turn towards a judicial continental body to address their concerns about undemocratic changes of term limits expands the range of AU responses to questions concerning constitutional changes involving term limits. However, once again, the ACtHPR's limited jurisdiction restricts its ability to establish legal accountability for processes of constitutional change. Only nine states allow individuals and non-governmental organizations (the most likely applicants) to bring issues to the court. This greatly affects the ACtHPR's effectiveness as an ultimate guarantor of fundamental rights and freedoms, including in contexts of constitutional change. This problem could be partially addressed if an application is first submitted to the ACHPR or if the ACHPR launches its own investigation, possibly authorized by the PSC, as in the case of Burundi (2015). The ACHPR could then bring the case to the ACtHPR, effectively expanding the ACtHPR's territorial jurisdiction to the 30 states that have ratified the protocol establishing the court. ${ }^{100}$ However, even if this is not done, as the court's jurisprudence continues to develop, other AU institutions, in particular the PSC, will have a yet stronger legal basis on which to justify intervening when constitutional change is accompanied by illegality.

In summary, the AU already has a legal and institutional framework that provides a basis for more robust engagement with constitutional change on the continent. However, as this article has argued with reference to the ACDEG, the agreed legal principles need to be elaborated upon to clarify their meaning and provide clearer authorization for the kind of AU engagement that will alert it to constitutional manipulation that may pave the way for undemocratic change (or extension) of governments. To complement a more sophisticated legal and policy framework, the mandates of monitoring mechanisms would also need to be expanded. It is not suggested that this will be easy. Without a significant continental push for conflict prevention and democracy, member states are likely to resist an increased role for the $\mathrm{AU}$ on the basis that it would constitute unacceptable interference in domestic affairs. Accordingly, as a first, modest, step, guidelines for constitutional change in Africa should be introduced, that allow the AU to pay greater attention to the indicators of constitutional manipulation outlined above.

99 Id, para 4.

100 African Charter, art 5(1)(a). 


\section{CONCLUSION: TOWARDS AFRICAN UNION GUIDELINES ON THE AMENDMENT OF CONSTITUTIONS IN AFRICA}

The AU is progressively refining its commitment to constitutional democracy through more detailed standard setting and more robust monitoring and enforcement mechanisms. However, serious challenges related to undemocratic constitutional changes, particularly during attempts to prolong executive tenure, remain and have exposed further problems that require attention. The frequent spill-overs of constitutional manipulation into popular uprisings and more profound constitutional and security crises, have led the AU to realise the need to strengthen its ability to prevent conflict. Further, the discrepancy between the legality and legitimacy of some regimes has led the AU to recognize the pressing need to evaluate the legitimacy of regimes against its broader agenda of democratization and constitutionalism.

This is the background against which the AU, through the PSC, called for the development of guidelines for constitutional amendment. ${ }^{101}$ In another decision, the AU Assembly of Heads of State and Government called upon member states to "ensure that constitutional amendments are done in accordance with the provisions of the ACDEG, as a baseline, and the active participation of their citizens". ${ }^{102}$ This conclusion aims to contribute to developing guidelines for constitutional change. It draws on the AU's existing law, policy and practice on constitutionalism and rule of law with particular reference to the ACDEG to construct a framework of four inter-related principles to govern democratic constitutional amendment processes. Importantly, these principles are linked to the factors signalling constitutional manipulation identified above, so that they provide the basis for a response to constitutional manipulation that is properly alert to the political, social and economic context and not limited to a formal, rule-based assessment. The four principles proposed are: adherence to formal rules and procedures (rule of law); peaceful environment (stability); respect for democratic rights (legality); and national consensus (legitimacy).

\section{Principles governing democratic constitutional change}

Adherence to formal rules and procedures

All constitutional reform processes need to respect the rules outlined in the constitution and any other legislation. ${ }^{103}$ This principle is a core element of the rule of law and constitutionalism, sometimes referred to as constitutional rule and constitutional order. It implies both complying with existing

101 PSC Press Statement of the 791st Meeting on 22 August 2018, (PSC/PR/BR (DCCXCI).

102 Decision on Governance, Constitutionalism and Elections in Africa (2016), Assembly/AU/Dec.592(XXVI).

103 ACDEG, preamble and arts 2(2), 3(2), 4(1), 5, 10, 14, 15 and 32(8). See also AU Constitutive Act, preamble and art $4(\mathrm{~m})$. See with specific reference to constitutional reform, the legally binding Decision on the Prevention of Unconstitutional Changes of Government, above at note 61, para 6(ii)(a). 
constitutional rules as well as refraining from any actions that may violate the Constitution and other laws relevant to constitutional change.

\section{A peaceful environment}

Constitutional change ideally takes place in a peaceful environment, ${ }^{104}$ free from political assassinations, ${ }^{105}$ police assaults (especially during public demonstrations) $)^{106}$ and undue interference from the security forces ${ }^{107}$ or party-affiliated militia groups. ${ }^{108}$

\section{Respect for democratic rights}

Constitutional change should take place in an environment in which democratic rights are respected. The rights that are especially relevant during the period leading up to constitutional change include: citizens' direct or indirect right of participation (which also forms part of their right to selfdetermination); ${ }^{109}$ freedom of expression, ${ }^{110}$ assembly ${ }^{111}$ and association; ${ }^{112}$ and the rights to liberty ${ }^{113}$ and personal security. ${ }^{114}$ Any limitations on these rights must comply with the standards set by African human rights bodies. ${ }^{115}$ If these rights are not upheld, not only will the entire process of constitutional change be flawed but no process of voting will meet the continental requirement that voting be free and fair, ${ }^{116}$ transparent ${ }^{117}$ and credible. ${ }^{118}$ To guarantee these rights the courts must be independent. For example, if judges have been dismissed or appointed in a manner that is inconsistent with the independence and impartiality of judges and the courts, citizens will not be assured that their rights are secure. In addition, other institutions that may be engaged in constitutional change, such as legislatures and, if a referendum is to be held, electoral commissions, must be sufficiently free from political

104 ACDEG, art 38.

105 AU Constitutive Act, art 4(o).

106 ACHPR "Guidelines for the policing of assemblies by law enforcement officials in Africa" (2017).

107 ACDEG, arts 14 and 32(5).

108 Decision on Governance, Constitutionalism and Elections, above at note 102.

109 African Charter, arts 13 and 20.

110 Id, art 9(2); ACDEG, arts 2(10) and 27(8).

111 African Charter, art 11.

112 Id, art 10.

113 Id, art 6.

114 Id, arts 4-5.

115 See, for example, ACHPR "Guidelines on freedom of association and assembly", above at note 89, paras 77-93. Also see, for example, ACtHPR jurisprudence in Konaté, above at note 90, paras 125-66 and Ingabire, above at note 90, paras 120-63, establishing standards for restrictions on freedom of expression.

116 Declaration on the Principles Governing Democratic Elections in Africa, AHG/Decl.1 (XXXVIII) (2002) establishes the main criteria for "free and fair" elections.

117 ACDEG, preamble and arts 2(3), 3(4), 17, 20 and 32 add the criterion of "transparency" for elections.

118 The benchmark for "credible" elections is established through the practice of the AUEOMs. 
pressure, ${ }^{119}$ and those bodies that may be required to assess the integrity of the process, such as courts or electoral commissions, must be impartial. ${ }^{120}$ When the principle of separation of powers is not adhered to, constitutional change is unlikely to comply with these guidelines. ${ }^{121}$

\section{National consensus}

The ACDEG requires constitutional change to be based on national consensus. ${ }^{122}$ The meaning of "consensus" in this context is not defined and, as constitutional amendment provisions in African constitutions show, it does not mean that everyone must agree. The requirement of national consensus is linked to the requirement that new constitutions and constitutional amendments need to be based on a broad social contract if they are to secure nation building and contribute to reducing conflict.

The requirement of national consensus has implications for the legitimacy of processes of constitutional change and their outcomes. To build national consensus the process itself must be inclusive, ${ }^{123}$ participatory ${ }^{124}$ and transparent. ${ }^{125}$ A rigid test cannot be set for inclusion, but at least it requires a process that includes social groups such as women, ${ }^{126}$ youth, ${ }^{127}$ older persons ${ }^{128}$ and people with disabilities, ${ }^{129}$ and that respects ethnic, cultural and religious diversity. ${ }^{130}$ Participation demands opportunities for people, including

119 See ACDEG, arts 2(5) and 32 for judicial independence. See id, art 15 for the independence of public institutions that promote and support democracy and constitutional order.

120 See id, art 17 for the independence and impartiality of election management bodies. In APDH $v$ Côte D'Ivoire, the ACtHPR clarified (para 118) that "an electoral body is independent where it has administrative and financial autonomy; and offers sufficient guarantees of its members' independence and impartiality". See also ACDEG, art 22 on independent and impartial national election monitoring or observation mechanisms.

121 ACDEG, art 3(5); Lomé Declaration.

122 ACDEG, arts 10(2) and 38. See also decisions by the PSC, AU Chairperson and AU Commission Chairperson, and recommendations by AUEOMs.

123 ACDEG, arts 8, 29, 31 and 38.

124 Id, preamble and arts 2(10), 3(7), 4(2), 27(2), 30 and 38. See also AU Constitutive Act, art 3(g); African Charter for Popular Participation in Development (1990); and the Lomé Declaration.

125 ACDEG, preamble and arts 3(8), 12, 13 and 33(2). Again, negotiation to reach a consensus should ideally be inclusive in the sense of including all sectors of society; however, this may be difficult to achieve post-conflict and failure to fulfil the principle of inclusivity in its broadest sense will not necessarily mark a process that fails the test of national consensus.

126 Id, art 29(2). Protocol to the African Charter on Human and Peoples' Rights on the Rights of Women in Africa (2003), art 9.

127 ACDEG, art 31. African Youth Charter (2006), art 11.

128 Protocol to the African Charter on Human and Peoples' Rights on the Rights of Older Persons in Africa (2016), art 5(3).

129 ACDEG, art 31(1). See also Protocol to the African Charter on Human and Peoples' Rights on the Rights of Persons with Disabilities in Africa (2018), arts 4, 21 and 22.

130 ACDEG, art 8(3). 
opposition groups, ${ }^{131}$ to engage in open debate. Further, when constitutional change requires a referendum, the absence of a minimum threshold for participation or a low requirement for approval may lead to decision making that lacks sufficient consensus. Transparency demands accessible information about the process, who is involved in any deliberative and decision-making bodies, and the issues that are on the agenda, as well as access to all relevant documentation (for example studies, preparatory documents, and advisory and consultation reports), expertise and initiatives related to the change.

\section{Monitoring and enforcement framework}

AU guidelines on constitutional change would ideally also clarify the way in which compliance with the principles they contain will be monitored and enforced. The principles could underline the value of AUEOMs in referenda and may be used in the recurrent evaluation of AU member state governance systems through the APRM country reports and the ACDEG state reporting mechanism. They could also inform the AU's conflict prevention agenda, permitting early responses that may avert later crises or be the basis for determining whether or not to impose sanctions in relation to infringements of article 23(5) of the ACDEG. Finally, the principles may serve as benchmarks for interpretation and adjudication by the (quasi)judicial bodies of the AU, namely the ACtHPR and ACHPR.

As the principles are applied and developed by AU monitoring and enforcement mechanisms, they will need to be updated to reflect the development of an African consensus on constitutional processes. Eventually, the AU might consider establishing an African Commission for Democracy Through Law, inspired by the Venice Commission, established under the Council of Europe. Such a commission, with a mandate to report on constitutional matters, could be instrumental in consolidating constitutionalism in Africa. Operating with respect for and understanding of the African context, such an advisory expert body could be responsible for the promotion of shared constitutional values, the interpretation of constitutional principles, advising on (draft) constitutions, constitutional amendments or during constitutional crises, and might provide constitutional assistance to national institutions, submit amicus curiae briefs to the ACtHPR, and develop guidelines and compilations of best practices and converging standards relevant to constitutional processes in Africa.

131 Id, art 3(11); Lomé Declaration. 